\title{
Performance Evaluation of Improved Water Management Technology of Rice at Farmers' Field in South-Eastern Rajasthan
}

\author{
R.S. Narolia*, Harphool Meena, Baldev Ram and B.L. Nagar
}

AICRP on Irrigation Water Management, Agricultural Research Station, Ummedganj, Kota (Agriculture University, Kota -324001, Rajasthan), India

*Corresponding author

\section{A B S T R A C T}

\begin{tabular}{|l|} 
Ke y w o r d s \\
$\begin{array}{l}\text { Rice, Sustainability } \\
\text { yield index, } \\
\text { Sustainability value } \\
\text { index and water } \\
\text { management } \\
\text { technology }\end{array}$ \\
\hline $\begin{array}{l}\text { Article Info } \\
\text { Accepted: } \\
\text { 20 June } 2018 \\
\text { Available Online: } \\
\text { 10 July } 2018\end{array}$ \\
\hline
\end{tabular}

On farm demonstrations were conducted during kharif seasons of 2013 to 2015 at farmer's field in Chambal command area of Rajasthan under Operational Research Programme of Agricultural Research Station, Kota to study the impact of improved water management technology on the water productivity and sustainability of rice. Treatments comprised irrigation of $5 \pm 2 \mathrm{~cm}$ standing water and refilling at 1-3 days after disappearance of ponded water which was compared with the farmers practice (FP) i.e. continuous submergence. Results revealed that improved water management technology gave higher and sustainable yield of rice over the years. The mean grain yield $(4,531 \mathrm{~kg} / \mathrm{ha})$, production efficiency (34.8 kg/ha/day) and crop monetary efficiency (Rs.728 /ha/day) recorded under IWMT being 7.0, 7.1 and 7.8 per cent higher as compared to the farmers practice, respectively. Mean sustainability yield index (0.913) and sustainability value index $(0.888)$ were found 2.87 and 4.0 percent higher under IWMT in comparison to FP, respectively. Mean water expanse efficiency $(92.9 \mathrm{~kg} / \mathrm{ha}-\mathrm{cm})$, water use efficiency $(35.2 \mathrm{~kg} / \mathrm{ha}-\mathrm{cm})$, water profitability (7.35 Rs. $/ \mathrm{M}^{3}$ ) and incremental cost benefit ratio (4.8) observed were also better in IWMP than farmers practice.

\section{Introduction}

Rice (Oryza sativa L.) is the most important staple food crop for nearly half of the world's population. It can grow well in standing water, but it does not require standing water as a rule. In the traditional practice water level of 9-10 $\mathrm{cm}$ is always maintain. This is because of farmer's belief that rice requires more water for better growth and good yield. Based on favourable monsoons, huge irrigation net work covering over $90 \mathrm{~m}$ ha has been developed since independence in the country that has made country self-sufficient in food grains production. However, the ever-growing competition over water, between farming and urban dwellers, and industrialists, is shrinking the available water resources for agriculture. The rapidly changing climate is also putting hurdles on the monsoon pattern and thus water supply to agriculture (Singh et al., 2013). It is in this context that efficient water use becomes more crucial in the coming years. There is also need to make food production 
less water dependant. Irrigated rice production system is the largest consumer of water in agriculture sector and its sustainability is threatened by increasing water shortage (Yang, 2012). Such water scarcity necessitates the development of alternate-irrigated rice system that requires less water than traditional-flooded rice (Naresh et al., 2013). Keeping in view of these emerging challenges, efficient production technology need to be developed and adopted utilizing the available water resources in the right perspective without compromising on production and productivity of rice, field trials were conducted at farmer's field under operational research programme (ORP) with the aim to increase water productivity of rice.

A total of 12 on farm trials (6 each at left main and right main canal of Chambal command) were conducted each year at adopted villages namely Manasganv, Soli, Kotsuan Mandawari of Kota and Kotkhera, Khothiya and Lesarda of Bundi districts during kharif seasons for five consecutive years (2013 to 2015) in the selected farmers' field. For the selection of farmers to conduct the demonstrations, a farmer's group meeting was convened each year and receptive and innovative farmers were selected. Selected villages of Chambal command lies between $25^{\circ}$ and $26^{\circ} \mathrm{N}$ latitude and $75^{\circ}-30^{\prime}$ and $76^{\circ}-6^{\prime} \mathrm{E}$ longitude in the south-eastern part of Rajasthan. It comes under agro climatic zone $\mathrm{V}$ which is also known as humid south eastern plain of Rajasthan.

The soils of the adopted villages for demonstrations belong to the order vertisols and inceptisols, mainly comprise of Chambal series $(62 \%)$ and Kota variant (23\%). The bulk density, $\mathrm{pH}$ and cation exchange capacity of these soils varies between $1.35-1.59 \mathrm{Mg} / \mathrm{m}^{3}$, 7.7 - 8.4 and $30-40 \mathrm{C} \mathrm{mol} / \mathrm{kg}$, respectively. The soils have a very low water intake rate approximately $0.25 \mathrm{~cm} / \mathrm{hr}$ on surface but are almost impermeable at 1.2 to $1.5 \mathrm{~m}$ depth. The potential moisture retention capacity is almost $120 \mathrm{~mm}$ of water in $1 \mathrm{~m}$ depth. The soils of the selected villages for demonstrations are poor in organic carbon $(0.50 \pm 0.07)$ and available nitrogen $(273 \pm 12 \mathrm{~kg} / \mathrm{ha})$ but are low to medium in available $\mathrm{P}_{2} \mathrm{O}_{5}(24.3 \pm 0.8 \mathrm{~kg} / \mathrm{ha})$ and medium to high in available $\mathrm{K}_{2} \mathrm{O}(295 \pm$ $10 \mathrm{~kg} / \mathrm{ha}$ ).

Improved water management practices (IWMP) includes irrigation of $5 \pm 2 \mathrm{~cm}$ standing water and refilling at 1-3 days after disappearance of ponded water and compared with the farmer's practice (FP) i.e. continuous submergence (usually $10 \mathrm{~cm}$ in each irrigation). Beside this, demonstrated blocks as well as control blocks were followed the recommended package of practices viz., high yielding varieties (Pusa Basmati-1121), seed treatment, nursery raising, recommended dose of fertilizer (120:60:60 NPK, kg/ha), crop geometry $(20 \mathrm{~cm} \times 20 \mathrm{~cm})$ and seed rate $(30$ $\mathrm{kg} / \mathrm{ha}$ ). Each trial was laid out in an area of 0.1 ha. For assessing impact of improved water management technology (IWMT), transplanting of paddy in adjoining field with similar area was also done by the farmer which was considered as control plot. For the test plots, measurement of water was done by velocity-area method at field level. The demonstration plots were transplanted with improved water management practices during first fortnight of July and harvested in the mid of October every year. The rainfall received during growing period of rice were $924.4 \mathrm{~mm}$, $734.6 \mathrm{~mm}$ and $592.2 \mathrm{~mm}$ with the total rainy days 39, 20 and 25 for the years of 2013, 2014 and 2015 respectively (Table 1). Potential yield of rice crop in humid south eastern plain zone of Rajasthan was $6000 \mathrm{~kg} / \mathrm{ha}$. Production efficiency was calculated on the basis of average maturity days (130 days) of variety Pusha Basmati-1121. Water productivity was also analyzed using standard method (Singh and Kumar, 2011). For economic evaluation in 
term of gross and net returns and incremental benefit ratio, the prevailing market rates for input, labour and produce was utilized. Data were recorded from demonstration blocks and farmer's practice blocks.

These recorded data were analyzed for different parameters, using following formulae, suggested by Prasad et al., (1993).
Extension
Gap=Demonstration yield(Di)- Farmers practice yield (Fi)
(B) Technology Gap= Potential yield(Pi)- Demonstration yield(Di)
(C) Technology Index $=($ Pi-Di $) / P i x 100$

Statistical analysis of the data for standard deviation and coefficient of variation was done as described by Panse and Sukhatme (1985). Sustainability indices (Sustainability yield index and sustainability value index) were work out using formula (Singh et al., 1990).

SYI $=$

Estimated average yield ( $\mathrm{kg} / \mathrm{ha})$ - Standard deviation

Maximum yield (kg/ha)

SVI =

Estimated net return (Rs./ha) - Standard deviation

Maximum net return (Rs./ha)

Water use efficiency $=$

Economic crop yield (kg/ha)

Evapotranspiration (ha.cm)

Water profitability $=$

Net return (Rs./ha)

Water applied $\left(\mathrm{m}^{3}\right)$

\section{Results and Discussion}

\section{Grain yield}

Cumulative data over three year (Table 3) revealed that mean grain yield $(4531 \mathrm{~kg} / \mathrm{ha})$, production efficiency $(34.8 \mathrm{~kg} / \mathrm{ha} /$ day $)$ and crop profitability ( $₹ 728 /$ ha/day) were found to be $7.0,7.1$ and 7.8 per cent higher under improved water management technology (IWMT) than mean grain yield (4230 kg/ha), production efficiency $(32.5 \mathrm{~kg} / \mathrm{ha} /$ day $)$ and profitability (₹675/ha/day) obtained under farmers practices, respectively. However, maximum production efficiency (36.9 $\mathrm{kg} / \mathrm{ha} /$ day) and crop profitability (₹801 kg/ha) under IWMT were recorded during 2014 and 2013, respectively. The higher grain yield and efficiency indices in relation to production and profitability during particular year and mean basis under demonstrated blocks could be attributed to the adoption of improved water management technology and higher sale price of produce. Year wise variations in grain yield and ultimately in efficiency indices were due to variation in the environmental conditions prevailed during that particular year. Narolia et al., (2013) also reported that improved water management practices have showed positive effect on yield potentials of paddy crop. Mean water expanse efficiency (92.9 $\mathrm{kg} / \mathrm{ha}-\mathrm{cm})$, water use efficiency $(35.2 \mathrm{~kg} / \mathrm{ha}-$ $\mathrm{cm})$ and water profitability $\left(7.35 ₹ / \mathrm{M}^{3}\right)$ which were 57.0, 28.3 and 29.8 per cent higher in test blocks as compared to farmers practice, respectively resulted due to optimal depth of irrigation water applied and by virtue of that more yield obtained. Dhar et al., (2011) reported similar results in rice crop at Jammu.

\section{Yield gap analysis}

Extension gap, Technology gap and Technological index were evaluated for all the three years. Extension gap is a parameter to know the yield difference between the 
demonstrated technology and farmer's practice; for study this ranged from 197 to 404 $\mathrm{kg} / \mathrm{ha}$ with an average of $302 \mathrm{~kg} / \mathrm{ha}$. This indicated a wide gap between the demonstrated improved technology and its adoption by the farmers (Table 4). Technology gap is a measure of difference between potential yield and yield obtained under improved water management technology demonstration, this is of greater significance than other parameters as it indicates the constraints in implementation and drawbacks in our package of practices, these could be environmental or varietal. This also reflects the poor extension activities, which resulted in lesser adoption of improved water management technology and package of practices by the farmers. Technology gap can be lowered down by strengthening the extension activities and further research to improve the package of practices. It is dependent on technology gap and is a function expressed in percent. For the three years of study it varied from 20.1 percent to 33.0 percent, with an average of 25.0 per cent. The very low technology index (20.1) during the year 2014 could be due to adoption of improved water management practices, favorable climatic conditions, free from insect pest and disease incidence. High technology index (33\%) observed in the year 2015 shows a poor performance of package of practices and demonstrated technology.

This was mainly due to early withdrawal of monsoon and unfavorable climatic conditions with incidence of pest and diseases. Such higher technology indices have been also reported in rice crop by Narolia et al., (2013).

Table.1 Weekly Rainfall and rainy day during Kharif 2013 to 2015

\begin{tabular}{|c|c|c|c|c|c|c|c|}
\hline \multirow{2}{*}{$\begin{array}{c}\text { Standard } \\
\text { week }\end{array}$} & Period & \multicolumn{3}{|c|}{ Total rainfall (mm) } & \multicolumn{3}{|c|}{ Rainy days } \\
\hline & from & 2013 & 2014 & 2015 & 2013 & 2014 & 2015 \\
\hline 27 & $2.7 .2009-8.7 .2009$ & 90.8 & 0.0 & 0.0 & 4 & 0 & $\mathbf{0}$ \\
\hline 28 & 9.7.2009-15.7.2009 & 35.6 & 29.2 & 92.8 & 3 & 0 & 5 \\
\hline 29 & 16.7.2009-22.7.2009 & 137.2 & 74 & 106.4 & 5 & 4 & 4 \\
\hline 30 & 23.7.2009-29.7.2009 & 190.8 & 96.4 & 189.2 & 6 & 4 & 5 \\
\hline 31 & 30.7.2009-5.8.2009 & 112.8 & 39.0 & 9.4 & 5 & 2 & 3 \\
\hline 32 & 6.8.2009-12.8.2009 & 142.9 & 333.6 & 44.4 & 6 & 4 & 2 \\
\hline 33 & 13.8.2009-19.8.2009 & 32.0 & 15.4 & 121.8 & 2 & 1 & 4 \\
\hline 34 & 20.8.2009-26.8.2009 & 75.1 & 0.0 & 0.0 & 4 & 0 & $\mathbf{0}$ \\
\hline 35 & 27.8.2009-2.9.2009 & 0.00 & 13.4 & 0.0 & 0 & 1 & $\mathbf{0}$ \\
\hline 36 & 3.9.2009-9.9.2009 & 0.00 & 114.8 & 5.8 & 0 & 3 & 1 \\
\hline 37 & 10.9.2009-16.9.2009 & 4.6 & 18.8 & 0.0 & 0 & 1 & $\mathbf{0}$ \\
\hline 38 & 17.9.2009-23.9.2009 & 22.2 & 0.00 & 0.00 & 1 & 0 & 1 \\
\hline 39 & 24.9.2009-30.9.2009 & 43.8 & 0.00 & 0.00 & 1 & 0 & $\mathbf{0}$ \\
\hline 40 & 1.10.2009-7.10.2009 & 7.4 & 0.00 & 0.00 & 1 & 0 & $\mathbf{0}$ \\
\hline 41 & $8.10 .2009-14.10 .2009$ & 29.2 & 0.00 & 0.0 & 1 & 0 & $\mathbf{0}$ \\
\hline & Total & 924.4 & 734.6 & 592.2 & 39 & 20 & 25 \\
\hline
\end{tabular}


Table.2 Effect of improved water management technology on sustainability yield and value index of paddy

\begin{tabular}{|c|c|c|c|c|c|c|c|c|c|}
\hline \multirow[t]{3}{*}{ Particulars } & \multicolumn{9}{|c|}{ Years } \\
\hline & & \multicolumn{2}{|c|}{2013} & \multicolumn{2}{|c|}{2014} & \multicolumn{2}{|c|}{2015} & \multicolumn{2}{|c|}{ Mean } \\
\hline & & IWMT & FP & IWMT & FP & IWMT & FP & IWMT & FP \\
\hline \multirow[t]{2}{*}{ Grain yield (kg/ha) range } & $\mathrm{H}$ & 5050 & 4690 & 5000 & 4800 & 4150 & 4040 & 4733 & 4510 \\
\hline & $\mathrm{T}$ & 4500 & 4020 & 4560 & 4070 & 3880 & 3630 & 4313 & 3907 \\
\hline Mean yield (kg/ha) & & 4775 & 4371 & 4797 & 4493 & 4022 & 3825 & 4531 & 4230 \\
\hline Standard deviation & & 167.1 & 181.4 & 146.6 & 184.0 & 89.1 & 103.1 & 134.3 & 156.1 \\
\hline CV $(\%)$ & & 3.50 & 4.15 & 3.06 & 4.10 & 2.21 & 2.70 & 2.92 & 3.65 \\
\hline \multirow[t]{2}{*}{ Net return range( $₹ / h a)$} & $\mathrm{H}$ & 111966 & 103174 & 104600 & 100636 & 84445 & 82832 & 100337 & 95547 \\
\hline & $\mathrm{T}$ & 96395 & 84206 & 92579 & 80692 & 76804 & 71229 & 88593 & 78709 \\
\hline Mean Net return (₹/ha) & & 104192 & 94136 & 99049 & 92244 & 80818 & 76759 & 94686 & 87713 \\
\hline Standard deviation & & 4730 & 5134 & 4006 & 5026 & 2521 & 2919 & 3752 & 4360 \\
\hline CV $(\%)$ & & 4.54 & 5.45 & 4.04 & 5.45 & 3.12 & 3.80 & 3.90 & 4.90 \\
\hline SYI & & 0.913 & 0.893 & 0.930 & 0.898 & 0.948 & 0.921 & 0.930 & 0.904 \\
\hline SVI & & 0.888 & 0.863 & 0.909 & 0.867 & 0.927 & 0.891 & 0.908 & 0.873 \\
\hline
\end{tabular}

$\mathrm{H}=$ Maximum yield at head reach of canal, $\mathrm{T}=$ Minimum yield at tail reach of canal IWMT=Improved water management technology $\mathrm{FP}=$ Farmers practice

Table.3 Effect of improved water management technology on grain yield, efficiency indices for water use and profitability of paddy

\begin{tabular}{|c|c|c|c|c|c|c|c|c|c|c|c|c|c|c|c|}
\hline \multirow[t]{2}{*}{ Year } & \multicolumn{2}{|c|}{ Yield (kg/ha) } & \multirow[t]{2}{*}{$\begin{array}{c}\% \\
\text { increase } \\
\text { over FP }\end{array}$} & \multicolumn{2}{|c|}{$\begin{array}{l}\text { Water applied } \\
\text { (cm) }\end{array}$} & \multicolumn{2}{|c|}{$\begin{array}{c}\text { WEE } \\
\text { (kg/ha-cm) }\end{array}$} & \multicolumn{2}{|c|}{$\begin{array}{c}\text { WUE } \\
\text { (kg/ha-cm) }\end{array}$} & \multicolumn{2}{|c|}{$\begin{array}{c}\mathbf{W P} \\
\left(₹ / \mathbf{M}^{3}\right)\end{array}$} & \multicolumn{2}{|c|}{$\begin{array}{c}\text { Production } \\
\text { efficiency } \\
\text { (kg/ha/day) }\end{array}$} & \multicolumn{2}{|c|}{$\begin{array}{l}\text { Monetary } \\
\text { efficiency } \\
\text { (₹ha/day) }\end{array}$} \\
\hline & IWMT & $\mathrm{FP}$ & & IWMT & FP & IWMT & FP & IWMT & $\mathrm{FP}$ & IWMT & $\mathrm{FP}$ & IWMT & FP & IWMT & FP \\
\hline 2013 & 4775 & 4371 & 9.2 & 130.6 & 152.6 & 125.7 & 72.9 & 36.6 & 28.6 & 7.98 & 6.17 & 36.7 & 33.6 & 801 & 724 \\
\hline 2014 & 4797 & 4493 & 6.8 & 125.5 & 143.5 & 92.3 & 64.2 & 38.2 & 31.3 & 7.89 & 6.43 & 36.9 & 34.6 & 762 & 710 \\
\hline 2015 & 4022 & 3825 & 5.2 & 130.7 & 154.7 & 60.9 & 42.5 & 30.8 & 24.7 & 6.18 & 4.96 & 30.9 & 29.4 & 622 & 590 \\
\hline Mean & 4531 & 4230 & 7.0 & 128.9 & 150.2 & 92.9 & 59.8 & 35.2 & 28.2 & 7.35 & 5.85 & 34.8 & 32.5 & 728 & 675 \\
\hline
\end{tabular}

WEE $=$ Water expanse efficiency, WUE $=$ Water use efficiency, WP= Water profitability 
Table.4 Economic analysis of improved water management technology on paddy at farmer's field

\begin{tabular}{|c|c|c|c|c|c|c|c|c|c|c|c|c|}
\hline \multirow[t]{2}{*}{ Year } & \multicolumn{2}{|c|}{$\begin{array}{l}\text { Cost of inputs } \\
(₹ \times 1000 / h a)\end{array}$} & \multirow{2}{*}{$\begin{array}{l}\text { Additiona } \\
\text { I cost in } \\
\text { IWMT } \\
\text { (₹/ha) }\end{array}$} & \multirow{2}{*}{$\begin{array}{l}\text { Sale } \\
\text { price } \\
(₹ / q)\end{array}$} & \multicolumn{2}{|c|}{$\begin{array}{l}\text { Total return } \\
\text { (₹/ha) }\end{array}$} & \multirow{2}{*}{$\begin{array}{l}\text { Additiona } \\
\text { I return } \\
\text { in IWMT } \\
(₹ / h a)\end{array}$} & \multirow{2}{*}{$\begin{array}{c}\text { Effective } \\
\text { gain } \\
\text { (₹./ha) }\end{array}$} & \multirow[t]{2}{*}{$\begin{array}{c}\text { IBC } \\
\mathbf{R}\end{array}$} & \multirow{2}{*}{$\begin{array}{c}\text { EG } \\
\text { (kg/ha) }\end{array}$} & \multirow{2}{*}{$\begin{array}{c}\text { TG } \\
(\mathrm{kg} / \mathrm{ha})\end{array}$} & \multirow{2}{*}{$\begin{array}{l}\text { TI } \\
(\%)\end{array}$} \\
\hline & IWMT & FP & & & IWMT & $\mathrm{FP}$ & & & & & & \\
\hline 2013 & 31.0 & 29.6 & 1400 & 2700 & 104192 & 94136 & 10056 & 8656 & 7.2 & 404 & 1225 & 20.4 \\
\hline 2014 & 32.0 & 30.5 & 1500 & 2600 & 99049 & 92244 & 6805 & 5305 & 4.5 & 304 & 1203 & 20.1 \\
\hline 2015 & 33.0 & 31.5 & 1500 & 2700 & 80818 & 76759 & 4059 & 2559 & 2.7 & 197 & 1978 & 33.0 \\
\hline Mean & 32 & 30.5 & 1467 & 2667 & 94686 & 87713 & 6973 & 5507 & 4.8 & 302 & 1469 & 25 \\
\hline
\end{tabular}

IWMT= Improved water management technology, FP= Farmers practices, EG= Extension gap, TG=Technology gap, TI= Technology Index 


\section{Economic analysis}

Mean data (Table 4) of three years revealed that 7.9 per cent higher net return was found in improved water management technology (₹94,686/ha) as compared to farmers practices. Grain yield, cost of inputs and sale price of produce determine the economic returns and these vary from year to year as the cost of input, labor and sale price of produce changes from time to time. The year wise additional returns from improved water management technology over farmer's practice varied from ₹ 4,059 to ₹ 10,056 . The mean additional cost of input of all the demonstrations for three years was ₹ 1,467 (Table 4). This additional investment along with non-monitory management factors gave an additional mean return of $₹ 6,973$. The higher sale price of produce, in spite of low production and higher additional cost of input during 2013 gave highest additional returns under improved technological demonstrations over farmer's practice. The incremental benefit cost ratio (IBCR) on overall average basis was 4.8. The highest IBCR during three years was observed in 2013 (7.2) this is due to comparatively higher grain yield, less cost of input and a good sale price. The results are in agreement with the findings of Singh et al., 2012.

\section{Sustainability}

The improved water management technology i.e. irrigation of $5 \pm 2 \mathrm{~cm}$ standing water and refilling at 1-3 days after disappearance of ponding water, gave higher grain yield, sustainability yield index and value index compared to the farmers practice. Higher standard deviation and ultimately coefficient of variation in yield observed under farmer's practices during all the experimental years was due to more variations in the yield from farmer to farmer and were lesser in improved water management technology. However, the sustainability yield index (SYI) and sustainability value index (SVI) were more under improved technology than farmer's practices (Table 1). The mean SYI under improved water management technology varied from 0.913 - 0.948 and SVI of 0.888 0.927 , whereas value of SYI under farmers practice ranged from $0.893-0.921$ and 0.863 -0.891 of SVI.

Mean data further revealed that SYI (0.930) and SVI (0.908) increased to the tune of 2.87 and 4.0 per cent over farmers practice. This showed that the improved water management technology is more sustainable as well as economical also as compared to farmer's practice. Chery et al., (2014) also observed similar trends in cotton based intercropping system under semi-arid vertisols.

In conclusion, the improved water management technology i.e. irrigation of $5 \pm 2$ $\mathrm{cm}$ standing water and refilling at 1-3 days after disappearance of ponded water, gave higher grain yield with saving of water, sustainability yield index and value index compared to the farmers practice.

\section{References}

Chery, G.R., Shriniwas, C.H., Shankar, G.R.M., Patel, P.G., Singh, R.N., Mganvir, M., Nagdeve, M.B., Mohad, V.D., Singh, R., Rani, $\mathrm{N}$ and Siddaram. 2014. Sustainability assessment of cotton based intercropping system for productivity and profitability using different quantitative indices under semi-arid vertisols. Indian Journal of Agronomy 59(4) : 587-595

Dhar, R., Bharti,V., Samanta, A., Gupta, N.K. and Bali, A.S. 2011. Water productivity enhancement of major crops in irrigated plains of Jammu. In proc: National seminar on "strategic 
resource management for sustainable food and water security". G.B. Pant University of Agriculture \& Technology Pantnagar (13-15 June 2011) Pp-2.

Naresh, R.K., Singh, S.P and Kumar vener. 2013. Crop establishment, tillage and water management technologies on crop and water productivity in ricewheat cropping system of North west India. International Journal of Life Sciences. Biotechnology and Pharma Research 2(3): 237-248.

Narolia, R.S., Pratap Singh., Mathur, I.N and Tetarwal, J.P. 2013. Assessment of gaps in transfer of water management technology in rice grown in Chambal Command of South -eastern Rajasthan. Annals Agril. Research. 34(3): 276-280

Panse, V.G. and Sukhatme, V.P. 1985. Statistical methods for agricultural workers. Indian Council of Agricultural Research, New Delhi.

Prasad, Y., Rao E, Manchar, M. and Vijaybhinanda, R. 1993. Analysis of on-farm trialsand level of technology on oilseeds and pulse crops in Northern Telangana Zone of Andra Pradesh. Indian J. Agril. Economics 48: 351-56.

Singh, R.P., Das, S.K., Bhaskar Rao, U.M and. Narayana Reddy, M. 1990.
Towards sustainable dryland agricultural practices. Bulletin, CRIDA, Hyderabad, India. Pp. 1-106. Singh, R., and Kumar, A. 2011. Mannual on Enhancing water use efficiency in canal command. Directorate of Water Management (ICAR), Bhubaneswar Pp-47-62

Singh, P., Narolia, R.S., Mathur, I.N., Sharma, N.N., Tomar, S.S. and Gupta, P.K. 2013. Enhancing crop productivity and water use efficiency in Chambal command area of Rajasthan: Prospectus and Perspectives. Proceedings of India Water Week on efficient water management: Challenges and Opportunities from 8-12 April, 2013 organized by Government of India, Ministry of water Resources. New Delhi.

Singh,T., Singh, R. and Soni, R.L. 2012. Performance of rice variety (P-1460) in front line demonstrations under rainfed conditions in southern humid region of Rajasthan. Annals of Agril. Sci. 33 (3): 121-125.

Yang, C.M. 2012. Technology to improve water management for rice cultivation to cope with climate change. Crop, Environment \& Bioinformatics 9: 193-207.

\section{How to cite this article:}

Narolia, R.S., Harphool Meena, Baldev Ram and Nagar, B.L. 2018. Performance Evaluation of Improved Water Management Technology of Rice at Farmers' Field in South-Eastern Rajasthan. Int.J.Curr.Microbiol.App.Sci. 7(07): 2727-2734. doi: https://doi.org/10.20546/ijcmas.2018.707.319 